\title{
Multistoried agroforestry garden system in West Sumatra, Indonesia
}

\author{
G. MICHON, ${ }^{1}$ F. MARY² and J. BOMPARD ${ }^{1}$ \\ 'Laboratoire de botanique, 163 rue A. Broussonnet, USTL, 34000 Montpellier, France \\ Present address: $C^{\circ}$ ORSTROM, BP 1286, Pointe Noire, Rep. du Congo \\ ${ }^{2}$ ENSA, Chaire de socio-economic rurale, 9 place Viala, 34060, Montpellier cedex, \\ France
}

Key words: buffer zone, commercial agroforestry, forest resource management, fruit trees, multistoried agroforest, West Sumatra

\begin{abstract}
The agroforestry garden system in Maninjau in West Sumatra is characterized by an intensive integration of forest species and commercial crops, forming a forestlike system. The intimate association of different species provides both subsistence and commercial products which supplement rice production. This complex agroforest is managed by the combination between cultural practices and respect of natural processes of vegetation production and reproduction. It represents a profitable production system. and constitutes an efficient buffer between villages and protected forest. It is a good model of association between integration of forest resources and cultivation of cash crops in the form of a sustainable and flexible system.
\end{abstract}

\section{Introduction}

The Minangkabau area in the province of West Sumatra of Indonesia is characterized by an ancient culture and a diversified agriculture that combines irrigated rice with perennial crops. Tropical forest that once dominated the area is now restricted to protected stations only. The district of Maninjau has developed impressive tree gardens which combine commercial tree crops and managed forest species, and dominate the agricultural landscape. These gardens originated a long time ago, probably from managed - or reestablished - forests associated with forest clearing for rice growing.

The Maninjau agroforestry system was studied intensively during the year 1983-1984 by a multidisciplinary team having special interest in forest botany and ecology, socio-economics and agronomy. Some detailed reports from this study have been prepared on different aspects such as the structure, architecture, botanic composition, use of plants and management practices of the system [5] and their socio-economic characteristics, production, relation with the other components of the production system, and place and role in the peasant economy [3].

Contribution No. 21 of the Series on Agroforestry System Descriptions under ICRAF's AF Systems Inventory Project, funded partially by the US Agency for International Development - USAID. (See Agroforestry Systems 1(3), 269-273, 1983, for project details). Series Editor: P.K.R. Nair, ICRAF.

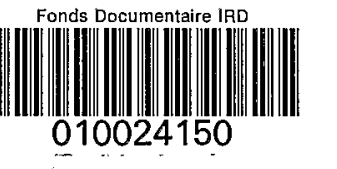

\section{Fonds Documentaire IRD Cote: B*24150 Ex: unigue}


This paper summarises the salient functional aspects of this interesting multistoried agroforestry system and evaluates its research needs and extrapolability.

\section{General description of the area}

\subsection{Geographic location}

The area of Maninjau is located in the Central part of the Province of West Sumatra $\left(0-1^{\circ} \mathrm{S}, 100^{\circ} \mathrm{E}\right)$ and belongs to the Minangkabau country. The location of the study area is indicated in Figure 1. The area covers about $300 \mathrm{~km}^{2}$, about a third of which consists of Maninjau lake, occupying the bottom of the ancient crater of Maninjau. It is bordered to the east by the rice-growing plateau of Bukittinggi (the heartland of Minangkabau country) and to the north by a remote mountain area. The crater opens to the west, by a narrow rift towards the coastal plain of Padang.

\subsection{Biophysical environment}

2.2.1 Climate: The area receives $3000-4500 \mathrm{~mm}$ of rain per year; the eastern part is the driest one. The rainfall peak occurs from October to March, with sometimes a short 'dry season' in February; the usual dry season (with less than $200 \mathrm{~mm}$ rainfall per month) is in July-August. Rainfall pattern is characterized by violent storms in the afternoons. The average temperature remains almost steady throughout the year at about $25^{\circ} \mathrm{C}$ at the lake level.

2.2.2 Topography and soils: Topography is characterized by the predominance of steep slopes. To the south and to the west, the lake is directly surrounded by very steep slopes (more than $40^{\circ}$ ) ending in a ridge up to the border of the crater; the lake terrace is less than $100 \mathrm{~m}$ wide. To the north and to the east, the terrace forms a wider plain, undulating on 500 to $2000 \mathrm{~m}$ up to the bottom of the crater slopes. The lake is at an altitude of $450 \mathrm{~m}$, and the crater ridges reach 1200 to $1500 \mathrm{~m}$ a.s.1.

Soils are young and loose volcanic soils (Andosols) that are rich in nutrients but are very unstable in structure and therefore prone to erosion and sliding. Numerous landslides occur during the rainy season and the soils on the lower parts of the slopes are rocky and stony, and poorly compacted on the upper parts of the crater. Peasants maintain a permanent and efficiently protective tree cover on the slopes to avoid serious landslides.

2.2.3 Vegetation: Natural vegetation is the tropical rainforest [7]. It still covers 30 to $79 \%$ of the total land area in different villages, and remains quite undisturbed from $900 \mathrm{~m}$ altitude up to the crater ridge. Above $800 \mathrm{~m}$ a.s.1., it is a typical mountain forest with Fagaceae (Quercus and Castanopsis), Lauraceae and Myrtaceae as canopy trees, and Anacardiaceae (Mangifera and Swintonia) or Shorea platyclados (Dipterocarpaceae) as emergents. Due 

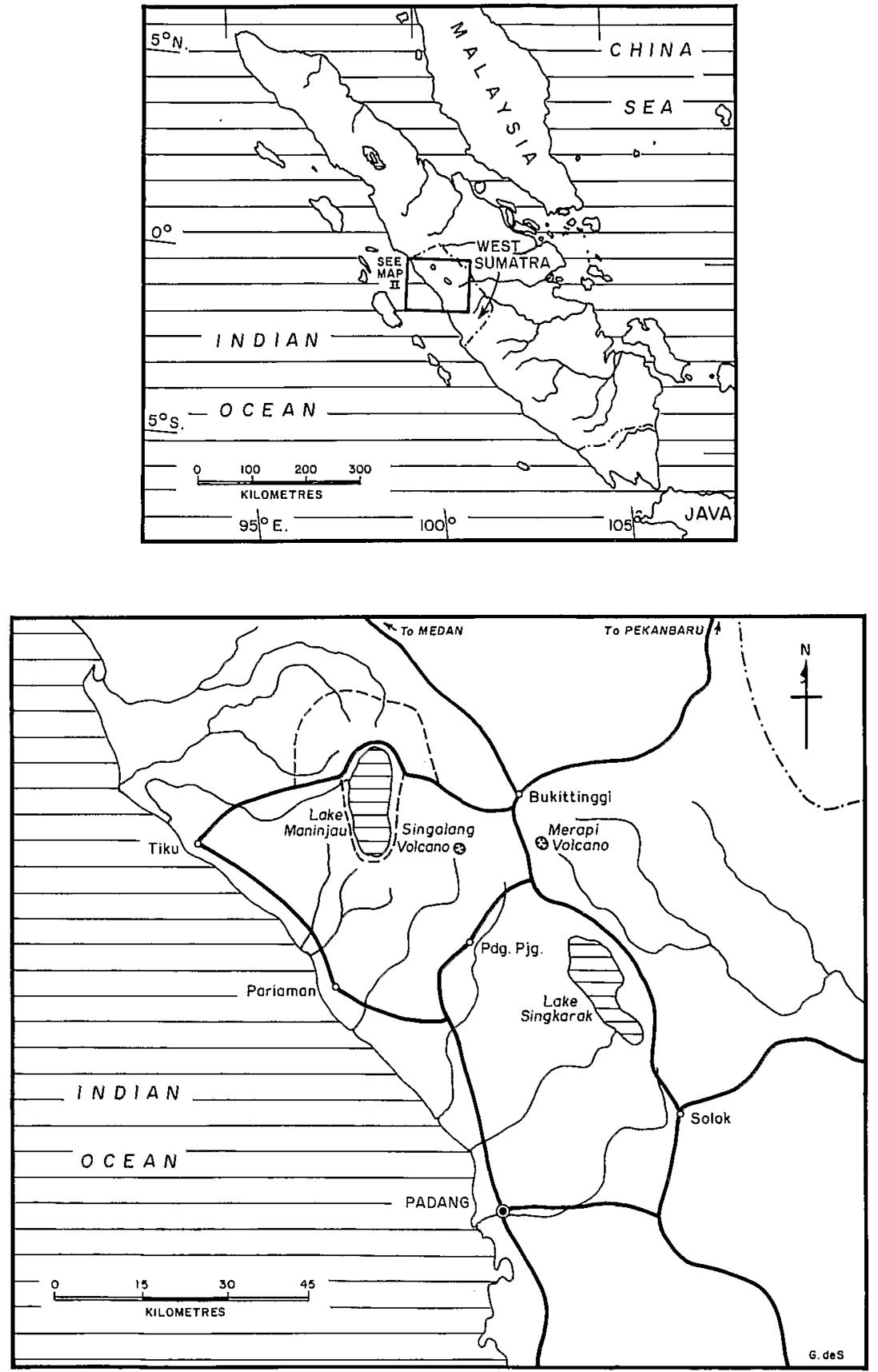

Figure 1. The location of the study area in West Sumatra. 
to the violent winds and landslides, this natural forest is highly perturbed: lianas are numerous (among which are Rattans) and big Ficus appear to be efficient soil 'stabilisers' with their abundant roots. On the steepest slopes, forest is replaced by bushy formation with Pandanus, ferns and herbs. Below $800 \mathrm{~m}$ a.s.1., what remains of the original forest is characterized by overstorey species of Burseraceae (Canarium, Santiria, Dacryodes), Fagaceae (Lithocarpus, Quercus), some spared Dipterocarpaceae (Shorea sumatrana, S. sororia, Hopea mengarawan, Parashorea lucida), a characteristic Mimosaceae (Acrocarpus fraxinifolius); the under-storey vegetation consists of Meliaceae (Aglaia argentea, A. gango, Chisocheton spp., Disoxylon macrocarpum, $D$. caulifonum, Toona sinensis), Lauraceae (Cinnamomum parthenoxylon, Litsea spp., Actinodaphne sp.), Annonaceae Euphorbiaceae, and Myristicaceae. Tree species of earlier successional formations are very common: Octomeles sumatrana (Datiscaceae), Alstonia angustiloba (Apocynaceae), Terminalia spp. (Combretaceae), Pisonia umbellifera (Nyctaginaceae), Artocarpus spp. (Moraceae). Most of these forest species are also frequently found in the agroforestry system and are retained and managed by peasants for various purposes.

\subsection{Land-use systems}

2.3.1 Agriculture: The area of Maninjau is characterized by a settled, smallholder agriculture with two major components:

- Rice cultivation on permanent irrigated ricefields located on the lake terraces and on the bottom of the slopes, covering 13 to $75 \%$ of the total agricultural land of villages (or 3.5 to $30 \%$ of the total land of villages). Rice production is mainly for home consumption, but surpluses are sold in some villages. One to three harvests per year are common depending on the availability of water and labour opportunities; rice fields are also planted with vegetable crops such as chillies, egg plant, cucumber, etc. between two rice crops.

- Mixed tree-gardens (the 'agroforest') for both commercial produces (spices, coffee, fruits) and subsistence purposes (wood, fruits, vegetables, etc.) are the other major agricultural system. This is described later (Sections 2.3.3 and 3).

A schematic presentation of the structural configuration and arrangement of these land-use systems is presented in Figure 2.

Livestock consists usually of chicken and some sheep or goats; in some villages, water buffaloes are also grown, mainly as draft animals for work in rice fields.

2.3.2 Forestry: There are no planted forests; wood for construction and other common uses is obtained from mixed tree gardens. Most of the natural forest above $900 \mathrm{~m}$ a.s.1. (on the steepest parts of the slopes) come under the status of 'Forest Reserve', which is State-managed. This status dates from the 


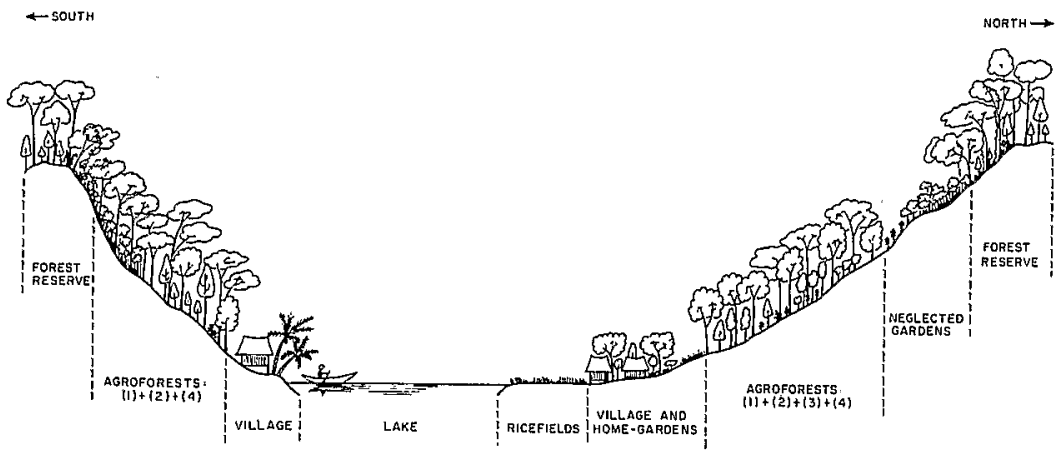

Figure 2. Schematic presentation of the agroforestry and land-use pattern in Maninjau. (1) durian + timber species + cinnamon + nutmeg + coffee; (2) timber species + nutmeg + cinnamon; (3) rejuvenated coffee garden with two-three overstorey timber/fruit trees; (4) neglected garden with some fruit trees + timber species and occasional agricultural species.

colonial period, but the boundaries of the reserve have been slight extended for several years by the Indonesian Forestry Services for protection purposes. Wood and rattan collection is strictly forbidden by law.

2.3.3 Agroforestry: The main agroforestry system consists of the tree gardens located on the slopes, between the villages and the forest reserve. A typical unit is shown in Figure 3. These gardens known as 'parak' make up 50 to 88\% of the agricultural land in different villages (13 to 33\% of the total land). They are characterized by high species diversity, high density of trees and a complex and layered vertical structure. They provide both commercial and subsistance wood products including typical minor forest products such as wild forest fruits and vegetables, forest medicines, etc. Agricultural tree crops such as cinnamon, nutmeg, coffee and cultivated fruits and shortduration crops such as chilli, tubers, beans are also obtained. Patterns of production and reproduction of the species are close to those in natural forest ecosystems; man's intervention is restricted to the harvest of products and some activities of planting concerning a few species.

Apart from these mixed-tree gardens, there are also the home gardens of villages as a minor component of the farms, but they are not developed around all houses. They include ornamental plants (in front of the house), and valuable fruit species that peasants are reluctant to grow in the slope gardens for security reasons.

2.3.4 Others: The lake is used for important fishing activities, especially in the southern and western parts of the crater. Fish is collected for home consumption and for sale on the crater markets. A particular kind of very small fish typical of Maninjau lake - the 'palai rinuak' - and a species of small mussel (the 'pensi') are exported to more important markets outside the crater. 


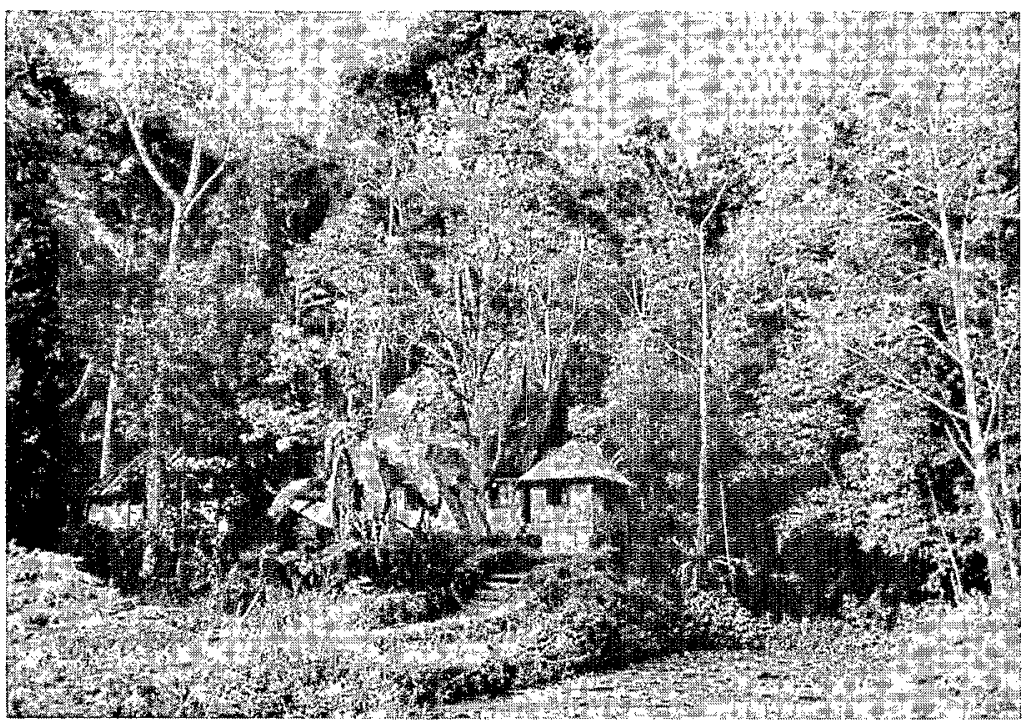

Figure 3. The transitional zone between the agricultural fields and agroforestry gardens. (Photo: G. Michon)

\subsection{Socio-economic characteristics}

2.4.1 Demographic patterns and land tenure: The general features and customs of Maninjau population are typical of the Minangkabau society. The population density in different villages varies from 150 to 350 inhabitants per $\mathrm{km}^{2}$. But during the past two decades the increase in population was only $10.5 \%$ as compared to $52 \%$ for the whole of Indonesia. This apparent low rate is due to a particular tradition of Minang people, viz., the voluntary migration of young men to neighbouring areas, or 'rantau', which in the past used to be only a temporary habit, but now tends to be a more definite part of their culture. In Maninjau, 40 to $70 \%$ of the 'original' population live outside the province, and young out-migrants and their wives and children do not wish to go back. This directly results in a 'loss' of young energy, and shortage in labour force for agricultural work; but it also reduces population pressure on land resources [6].

The Minang society is matrilinear. The social unit is the enlarged family. Land and trees are owned communally by the clan. Usually, ricefield land is temporarily shared among married daughters but for the tree garden land, sharing may concern only trees, or their produce, depending on several factors such as the nature of trees, their pattern of production, person who had planted the tree and so on. In Maninjau, the upkeeping of a garden - but not the control over land or tree produce - is handled by one person who has the right to plant new trees or annual crops and harvest for her/himself what 
(s)he has planted (trees concerned are mainly coffee, cinnamon and wood species). But the produce of other trees (fruits of long-lived wood species and nutmeg) is shared among all the members of the clan, and decisions concerning the sale or mortgaging of a piece of land have to be taken communally. This land tenure system is a good warranty against the excessive subdivision and fragmentation of productive land and against the accumulation of owner. ship by rich people; it also reduces the chances for any sudden transformation of the agricultural system: a land cannot be sold or transformed, a tree cannot be cut by individual decision of a single owner [8] - however, this may have good as well as bad consequences.

2.4.2 Characteristics of farms and villages: The size and the form of the management units are not uniform. Three situations from three different villages are presented in Table 1 , which reflect the heterogeneity among the villages [3] :

village 1: large extension of agricultural land and ricefields;

village 2: irrigated ricefields and total agricultural land not so extended, but intensively managed; tree gardens well developed;

village 3: scarcity of agricultural land, particularly of ricefields; tree gardens dominate.

2.4.3 Road and market facilities: Maninjau is presently well related to the neighbouring areas: car can reach the international harbour of Padang (100 $\mathrm{km}$ ) by a new road (about three hours), and the main regional market centre of Bukittinggi $(40 \mathrm{~km})$ in two hours. There are regular services of public transportation from villages of the northern and eastern parts of the crater. However, the villages in the south and west have no roads suitable for vehicles, and the main mode of traffic is small boats crossing the lake to the district centre or to the western road out of the crater.

There are cooperatives for rice cultivation and processing or sale in each part of the crater, and a cooperative dealing with cultivation and marketing of spices and coffee for the south-eastern part. In other areas, marketing of products occurs through local traders. Credit facilities are developed only for rice.

\section{Structure of the system}

Agroforests in Maninjau are not homogeneous, either in composition or in structure. The different combinations between crops, and between cultivated and spontaneous components result from historic and economic criteria. However, they form a dense, forest-like cover on the slopes [5].

\subsection{Components of the agroforest}

3.1.1 Cultivated annual crops: Annual - or short-cycle - crops are by no 
Table 1. Socio-economic characteristics of some typical farms and villages in Maninjau, Western Sumatra

\begin{tabular}{|c|c|c|c|c|c|c|}
\hline \multirow[t]{2}{*}{ Characteristics } & \multicolumn{2}{|c|}{ Village 1} & \multicolumn{2}{|c|}{ Village 2} & \multicolumn{2}{|c|}{ Village 3} \\
\hline & $\begin{array}{l}\text { Total } \\
\text { area } \\
\text { (ha) }\end{array}$ & $\begin{array}{l}\% \text { of } \\
\text { agricultural } \\
\text { area }\end{array}$ & $\begin{array}{l}\text { Total } \\
\text { area } \\
\text { (ha) }\end{array}$ & $\begin{array}{l}\% \text { of } \\
\text { agricultural } \\
\text { area }\end{array}$ & $\begin{array}{l}\text { Total } \\
\text { area } \\
\text { (ha) }\end{array}$ & $\begin{array}{l}\% \text { of } \\
\text { agricuitural } \\
\text { area }\end{array}$ \\
\hline \multirow{6}{*}{$\begin{array}{l}\text { Total village land } \\
\text { Total agricultural area } \\
\text { Total area of rice fields } \\
\text { Total area of 'agroforest' } \\
\text { (mixed gardens) } \\
\text { Total area of other agric. } \\
\text { land - homegardens, } \\
\text { abandoned fields - }\end{array}$} & 1800 & & 1000 & & 750 & \\
\hline & 1250 & 100 & 640 & 100 & 160 & 100 \\
\hline & 540 & 43 & 220 & 34 & 20 & 12 \\
\hline & 280 & 22 & 342 & 53 & 100 & 63 \\
\hline & & & & & & \\
\hline & 434 & 35 & 80 & 13 & 40 & 23 \\
\hline $\begin{array}{l}\text { Ratio agroforest area/ } \\
\text { rice field area }\end{array}$ & \multicolumn{2}{|c|}{0.5} & \multicolumn{2}{|l|}{1.6} & \multicolumn{2}{|l|}{5} \\
\hline $\begin{array}{l}\text { Total population living } \\
\text { in the village }\end{array}$ & \multicolumn{2}{|l|}{2302} & \multicolumn{2}{|l|}{3453} & \multicolumn{2}{|l|}{1200} \\
\hline $\begin{array}{l}\text { Number of households in } \\
\text { the village } \\
\% \text { of original village }\end{array}$ & \multicolumn{2}{|l|}{416} & \multicolumn{2}{|l|}{540} & \multicolumn{2}{|l|}{204} \\
\hline $\begin{array}{l}\text { population living } \\
\text { outside the province }\end{array}$ & \multicolumn{2}{|l|}{50} & \multicolumn{2}{|l|}{60} & \multicolumn{2}{|l|}{70} \\
\hline Population density $/ \mathrm{km}^{2}$ & \multicolumn{2}{|l|}{128} & \multicolumn{2}{|l|}{345} & \multicolumn{2}{|l|}{$\begin{array}{r}70 \\
160\end{array}$} \\
\hline $\begin{array}{l}\text { to the area of cultivated } \\
\text { land }\end{array}$ & \multicolumn{2}{|l|}{185} & \multicolumn{2}{|l|}{540} & \multicolumn{2}{|l|}{750} \\
\hline $\begin{array}{l}\% \text { of household with non- } \\
\text { farming main activity }\end{array}$ & \multicolumn{2}{|l|}{1} & \multicolumn{2}{|l|}{16} & \multicolumn{2}{|l|}{11} \\
\hline $\begin{array}{l}\text { Mean }(M) \text { and range }(R) \text { of } \\
\text { Ricefield unit size (ha) }\end{array}$ & \multicolumn{2}{|c|}{$\begin{array}{l}M: 1.3 \\
R: 0.5 \text { to } 2\end{array}$} & \multicolumn{2}{|c|}{$\begin{array}{l}\text { M: } 0.4 \\
\text { R: } 0.1 \text { to } 0.7\end{array}$} & \multicolumn{2}{|c|}{$\begin{array}{l}\mathrm{M}: 0.1 \\
\mathrm{R}: 0.01 \text { to } 0.3\end{array}$} \\
\hline $\begin{array}{l}M \text { and } R \text { of agroforest } \\
\text { size (ha) }\end{array}$ & \multicolumn{2}{|c|}{$\begin{array}{l}M: 0.67 \\
R: 0.1 \text { to } 3\end{array}$} & \multicolumn{2}{|c|}{$\begin{array}{l}\text { M: } 0.63 \\
\text { R: } 0.05 \text { to } 2\end{array}$} & \multicolumn{2}{|c|}{$\begin{array}{l}\text { M: } 0.5 \text { unit } \\
\text { R: } 0.01 \text { to } 2\end{array}$} \\
\hline $\begin{array}{l}M \text { and } R \text { of agricultural } \\
\text { land per household (ha) }\end{array}$ & \multicolumn{2}{|c|}{$\begin{array}{l}\text { M: } 3 \\
\text { R: ño data }\end{array}$} & \multicolumn{2}{|c|}{$\begin{array}{l}\text { M: } 1.18 \\
\text { R: no data }\end{array}$} & \multicolumn{2}{|c|}{$\begin{array}{l}\text { M: } 0.8 \\
\text { R: no data }\end{array}$} \\
\hline
\end{tabular}

means dominant in the agroforest; they form a temporary, occasional component which appear at the time of renovation of the undergrowth of gardens, often in association with cinnamon, coffee or nutmeg. These are the same crops which can be grown in ricefields between two rice harvests: chilli (Capsicum annuum), egg plant (Solanum melongena), maize (Zea mays), beans (Vigna spp., Phaseolus spp.), cucumber (Cucumis sativus), bananas (Musa paradisiaca), papaya (Carica papaya), etc. Tuber crops are avoided because of the high degree of depredation by wild pigs.

3.1.2 Tree crops: These include only planted trees which receive care and attention and are systematically harvested. Agroforests usually have only 6 common cultivated tree crops. 
Durio zibethinus (Bombacaceae), durian. A large tree up to $40 \mathrm{~m}$ high, producing large fruits, is the main component of the agroforest canopy and the main tree species of Maninjau. It originates from natural forest of Western Indonesia, bears fruits in July-August, from the age of 7 years to more than 100 years. Fruits are both sold to local traders and abundantly consumed; in peak seasons, durian surpasses rice in quantity of consumption. Durian is propagated from seeds collected from the best fruits and planted in chosen places in the gardens. The trees receive no special care, but before fruiting season, the undergrowth of the gardens is cleared in order to facilitate a better collection of the fallen fruits. The trees are let to die naturally and often fall down during big storms; wood is collected for construction purposes; it yields a valuable red wood suitable for partition panels (walls).

Pterospermum javanicum (Sterculiaceae). This large canopy tree, up to $35-40 \mathrm{~m}$ high is common in coastal and low-mountain forest in Sumatra. In the gardens, it is found in association with durian. It is a fast growing tree, grown for construction wood; it yields a red wood suitable for flooring and walls. It is propagated from spontaneous seedlings occuring in the gardens and can be harvested after 15-20 years; it can yield 30 to 50 boards (300$400 \mathrm{~cm} \times 22 \mathrm{~cm} \times 3-4 \mathrm{~cm}$ ), for a diameter (dbh) of 35 to $50 \mathrm{~cm}$.

Toona sinensis (Meliaceae). A medium-sized tree native of local forests, growing up to $35 \mathrm{~m}$ high, is a valuable shade tree for coffee and nutmeg. It yields a good timber; is used for flooring or walls, and for furniture. It is propagated from seedlings that are collected from cleared places under mature trees (the seed needs a certain amount of light to germinate), and is harvested from the age of 30 years. A tree of $30 \mathrm{~cm}$ in diameter can yield about 25 boards $(400 \times 22 \times 4 \mathrm{~cm})$.

Cinnamomum burmani (Lauraceae), cinnamon. It is one of the major export crops for West Sumatra, and for centuries has been cultivated in Maninjau. In the agroforests, it is one of the three major under-storey species; is grown under a dense stand of durian, Pterospermum and other species, from seedlings collected in the gardens and kept in nursery for one year, or preferably from coppice shoots occuring after harvest. Bark can be harvested when the tree is $8-10$ years old (dbh above $10 \mathrm{~cm}$; total height up to $15 \mathrm{~m}$ ). For harvesting, the tree is cut and bark of trunk and branches collected; the average yield is of $8 \mathrm{~kg}$ of dry bark per tree; wood, from which the bark has been peeled off, is also collected as fuelwood for home consumption or sale.

The average density of a cinnamon stand in the gardens varies between 800 and 1500 trees/ha, depending on the type of association with overstorey trees and with nutmeg, and on the strategy chosen for harvest: the stand can be harvested at once, and then replanted totally, or regularly collected (10 to 20 trees cut every year, which are allowed to regenerate to produce coppice shoots). Yields are better in dense stands and upper parts of the slopes $(C$. burmani is a tree native of the mountain forests - over $900 \mathrm{~m}$ a.s.1. - in Sumatra and it can be grown at lower altitudes only under a dense canopy of shade trees which maintain a humid and cool microclimate). 
Myristica fragans (Myristicaceae), nutmeg. This medium-sized tree, up to $20 \mathrm{~m}$ high, is a native of the eastern parts of the Indonesian archipelago. Nutmeg is grown from seeds collected from mature trees and kept in nurseries for one year, seedlings are established under a light canopy of durian and Toona, and can be associated with a cinnamon stand. Densities for nutmeg vary from 300 to 500 trees/ha. The tree bears fruits at the age of six, and can produce for 50 to 70 years. There is no proper fruiting season, but peaks are in July and January. Average yields vary from 10 to $30 \mathrm{~kg}$ of dry nuts per tree; macis is also collected and dried.

Coffea canephora (= C. robusta). (Rubiaceae), coffee. Coffee has been a dominant component of agroforestry systems until about 1940 , when cultivation was abandoned. But it has recently been re-established. Coffee is planted from seedlings collected from neglected plantations on the upper parts of the slope, under a light canopy of durian. During the early years of establishment, young coffee trees are associated with banana and papaya trees; at the same time young Toona trees as well as some Pterospemum, Alangium, Leucaena and Actinodaphne are planted within the coffee stand. The stand is manured with decomposed pericarp of durian fruits. Pruning of coffee trees is not a common practice. The level of production is generally low: an average of $120 \mathrm{~kg}$ of dry fruit per ha. The peak of production is in July-August, although there is some fruiting all over the year. There is no sole crop stand of coffee in these agroforests. After the dramatic decline in coffee economy in the 1930s, peasants have become careful to associate coffee (and commercial crops in general) with fruit trees and wood species that have a long and proven history in the socio-cultural set up of the villages, so that these trees act as shade trees for coffee and improve the total output from the garden land.

3.1.3 Other tree and shrub species: Many other species are important in the agroforest; there are planted species or species reproducing through natural seedlings without any human intervention, but are retained, managed and harvested for various purposes. These are species originating from the native forest as well as pioneer species from secondary formations or species from the 'cultivated' world. A list of such species is given in Table 2.

In addition, many plants are collected as medicinals or for traditional uses. Other species with no particular use are considered as soil improvers; these include Eupatorium odoratum, a common weed, Pisonia umbellifera, a large tree with smooth wood, Laportea stimulans, a dangerous Urticaceae, etc.

3.1.4 Animals: some buffaloes are kept for grazing in the agroforest, but the main animal component is the wild fauna: its role in pollination and seed dispersion is important, but it represents a major danger for fruit and tuber crops. Main depredators are monkeys (Presbytis rubiconda, the leaf monkey; Macaca nemestrina and $M$. fascicularis, the macaques; some gibbons: Hylobates syndactylus), civets and squirrels, and wild pigs. The Malay sunbear 
Table 2. List of 'non-cultivated' but useful trees species in Maninjau Agroforestry systems

\begin{tabular}{|c|c|c|c|}
\hline Main use & $\begin{array}{l}\text { Growth } \\
\text { form }\end{array}$ & *Origin & Secondary use \\
\hline \multicolumn{4}{|l|}{ Construction Wood } \\
\hline $\begin{array}{l}\text { Acrocarpus fraxinifolius (Mimis) } \\
\text { Actinodaphne sp. (Laurac) } \\
\text { Aglaia spp. (Meliac.) } \\
\text { Alangium kurzii (Alang.) } \\
\text { Alstonia angustiloba (Apoc.) } \\
\text { Antidesma sp. (Euphorb.) } \\
\text { Bishofia javanica (Euphorb.) } \\
\text { Carallia brachyata (Rhizoph.) } \\
\text { Dysoxylon spp. (Meliac.) } \\
\text { Litsea spp. (Laurac.) } \\
\text { Macaranga tanarius (Euphorb.) } \\
\text { Mallotus spp. (Euphorb.) } \\
\text { Morus macroura (Euphorb.) } \\
\text { Nauclea spp. (Rubiac.) } \\
\text { Parashorea lucida (Diptero.) } \\
\text { Shorea sumatrana (Diptero.) } \\
\text { Shorea platyclados (Diptero.) } \\
\text { Shorea spp. (Diptero.) } \\
\text { Toona surenii (Meliac.) } \\
\text { Trema orientalis (Ulmac.) }\end{array}$ & $\begin{array}{l}\text { tree } \\
\text { tree } \\
\text { tree } \\
\text { tree } \\
\text { tree } \\
\text { small tree } \\
\text { tree } \\
\text { tree } \\
\text { tree } \\
\text { tree } \\
\text { small tree } \\
\text { small tree } \\
\text { tree } \\
\text { treelet } \\
\text { tree } \\
\text { tree } \\
\text { tree } \\
\text { tree } \\
\text { tree } \\
\text { tree }\end{array}$ & $\begin{array}{l}\text { FI } \\
\text { FI } \\
\text { FI } \\
\text { FI \& FII } \\
\text { FI \& FII } \\
\text { FII } \\
\text { FII } \\
\text { FI } \\
\text { FI } \\
\text { FI } \\
\text { FII } \\
\text { FI \& FII } \\
\text { FII } \\
\text { FII } \\
\text { FI } \\
\text { FI } \\
\text { FI } \\
\text { FI } \\
\text { FI } \\
\text { FII }\end{array}$ & $\begin{array}{l}\text { all species also used as } \\
\text { fuel wood } \\
\ldots \ldots \ldots\end{array}$ \\
\hline \multicolumn{4}{|l|}{ Fruits } \\
\hline $\begin{array}{l}\text { Annona muricata (Anon.) } \\
\text { Artocarpus integer (Morac.) } \\
\text { Art. heterophyllus (Morac.) } \\
\text { Averrhoa bilimbi (Oxalid.) } \\
\text { Aver. carembola (Oxalid.) } \\
\text { Baccaurea spp. (Euphorb.) }\end{array}$ & $\begin{array}{l}\text { treelet } \\
\text { tree } \\
\text { tree } \\
\text { treelet } \\
\text { treelet } \\
\text { trees }\end{array}$ & $\begin{array}{l}\mathrm{HG} \\
\text { FI, HG } \\
\text { HG } \\
\text { HG } \\
\text { HG } \\
\text { FI \& HG }\end{array}$ & $\begin{array}{l}\text { wood for houses and } \\
\text { tools } \\
\text { construction wood } \\
\text { very good timber } \\
\text { (hardwood) }\end{array}$ \\
\hline $\begin{array}{l}\text { Citrus grandis, C. hystrix, } \\
\text { C. aurantifolia, C. microcarpa, } \\
\text { C. medica, C. sinensis (Rutac.) } \\
\text { Eugenia aquea, E. malaccensis, } \\
\text { E. javanica, E. michelii (Myrtac) }\end{array}$ & $\begin{array}{l}\text { trees } \\
\text { trees }\end{array}$ & $\begin{array}{l}\text { FI \& HG } \\
\text { FI \& HG }\end{array}$ & $\begin{array}{l}\text { common for medicine } \\
\text { wood for houses or } \\
\text { others }\end{array}$ \\
\hline $\begin{array}{l}\text { Garcinia mangostana (Guttif.) } \\
\text { F. rukem (Flacourt). } \\
\text { Lansium domesticum (Meliac.) }\end{array}$ & $\begin{array}{l}\text { tree } \\
\text { tree } \\
\text { tree }\end{array}$ & $\begin{array}{l}\text { HG } \\
\text { FI \& II } \\
\text { HG }\end{array}$ & $\begin{array}{l}\text { good hardwood for } \\
\text { houses }\end{array}$ \\
\hline $\begin{array}{l}\text { Mangifera indica (Anacard.) } \\
\text { Mangifera foetida } \\
\text { Mangifera odorata }\end{array}$ & $\begin{array}{l}\text { tree } \\
\text { tree } \\
\text { tree }\end{array}$ & $\begin{array}{l}\text { HG } \\
\text { FI, HG } \\
\text { FI \& HG }\end{array}$ & $\begin{array}{l}\text { construction wood } \\
\text { and leaves as } \\
\text { vegetables }\end{array}$ \\
\hline $\begin{array}{l}\text { Nephelium lappaceum (Sapind.) } \\
\text { Musa paradisiaca (Musac.) }\end{array}$ & $\begin{array}{l}\text { tree } \\
\text { herbac. }\end{array}$ & $\begin{array}{l}\text { HG \& FI } \\
\text { HG \& FII }\end{array}$ & $\begin{array}{l}\text { leaves as wrapping } \\
\text { material }\end{array}$ \\
\hline $\begin{array}{l}\text { Psidium guajava (Myrtac.) } \\
\text { Salacca edulis (Arec.) } \\
\text { Spondias cytherea (Anac.) }\end{array}$ & $\begin{array}{l}\text { treelet } \\
\text { palm } \\
\text { tree }\end{array}$ & $\begin{array}{l}\text { HG } \\
\text { HG \& FI } \\
\text { HG }\end{array}$ & \\
\hline
\end{tabular}


Table 2. List of 'non-cultivated' but useful trees species in Maninjau Agroforestry systems (continued)

\begin{tabular}{|c|c|c|c|}
\hline Main use & $\begin{array}{l}\text { Growth } \\
\text { form }\end{array}$ & *Origin & Secondary use \\
\hline \multicolumn{4}{|l|}{ Vegetables and Spices } \\
\hline $\begin{array}{l}\text { Aleurites moluccana (Euphorb.) } \\
\text { Claoxylon spp. (Euphorb.) } \\
\text { Eugenia polyantha (Myrtac.) } \\
\text { Parkia speciosa (Mimos.) } \\
\text { Pithecellobium jiringa (Mimos.) } \\
\text { Pangium edule (Flacourt.) }\end{array}$ & $\begin{array}{l}\text { tree } \\
\text { bush } \\
\text { tree } \\
\text { tree } \\
\text { tree } \\
\text { tree }\end{array}$ & $\begin{array}{l}\text { introd. } \\
\text { FI \& FII } \\
\text { FI \& HG } \\
\text { FI } \\
\text { FI } \\
\text { FI }\end{array}$ & construction wood \\
\hline $\begin{array}{l}\text { Areca spp. (Arecac.) } \\
\text { Arenga pinnata (Arecac.) }\end{array}$ & $\begin{array}{l}\text { palm } \\
\text { palm }\end{array}$ & $\begin{array}{l}\text { FI } \\
\text { FI }\end{array}$ & $\begin{array}{l}\text { sugar palm }+ \text { fibers } \\
\text { for roofing }\end{array}$ \\
\hline $\begin{array}{l}\text { Ferns: } \\
\text { Dichtyopteris irregularis, } \\
\text { Diplazium esculentum, } \\
\text { Stenochlaena palustris } \\
\end{array}$ & herbs & FI & \\
\hline \multicolumn{4}{|l|}{ Others } \\
\hline $\begin{array}{l}\text { Pandanus tinctorius (Pandanac.) } \\
\text { Many bamboo species }\end{array}$ & bush & $\begin{array}{l}\text { FI } \\
\text { FI }\end{array}$ & $\begin{array}{l}\text { leaves for handicraft } \\
\text { food, material for } \\
\text { cooking }\end{array}$ \\
\hline
\end{tabular}

*FI = primary forest, $\mathrm{FII}=$ secondary formations, $\mathrm{HG}=$ often cultivated in the home garden

(Helarctos malayanus), the 'binturong' (Arctidis binturong), some tigers and wild cats, wild goats (Capricornis sumatraensis), may represent, to a lesser extent, some danger for crops or people.

\subsection{Arrangement of components}

One of the most distinguishing features of the mixed gardens is the species diversity; there is no single perennial species that dominates the gardens. Factors influencing the composition and the architecture of the gardens include: size of the agroforest plot in relation to that of the ricefield plot managed by the family, degree of clearing cares, cash vs. consumption needs of the family and location of the plot (in altitude as well as its location in the crater). However, all the plots are characterized by an intimate arrangement between overstorey and understorey species, which can be analysed by using the terms of forest-ecosystem analysis: vegetation structure and architecture are characterized by different layers of mature productive trees which are defined as 'structural ensembles' or 'producing ensembles' [4] .

Depending on the dominant tree crops in the plot, two schematic types of gardens can be described as follows:

3.2.1 Durian + wood species + cinnamon/nutmeg combination. In this first type of garden, two structural ensembles of productive trees are dominant: the canopy ensemble comprising Durio and Pterospermum occupies the upper strata (up to $40 \mathrm{~m}$ high, relative cover equals $90 \%$ of the plot surface and the 


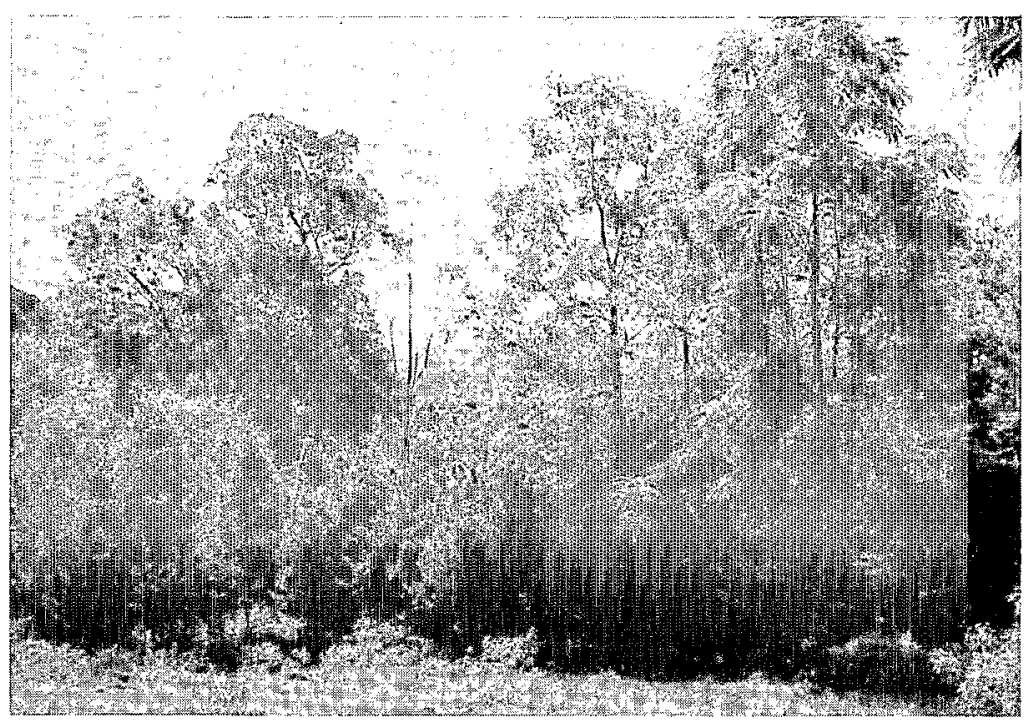

Figure 4. An agroforestry garden with durian (on the left side) and Toona sinensis (on the right side) as the overstorey species and nutmeg as the understorey species. (Photo: G. Michon)

tree density is about 110 productive trees/ha). Cinnamon or nutmeg stand forms a lower ensemble between 5 and $15 \mathrm{~m}$ high which covers up to $70 \%$ of the plot surface. Between these two distinct ensembles, discontinuous tree layers are also present, notably one between 18 and $22 \mathrm{~m}$ high with Toona and Alangium and another between 5 and $12 \mathrm{~m}$ high with fruit species, the latter interfering with the nutmeg/cinnamon ensemble. Ground layer is occupied by spontaneous grasses and by some Pandanus. Young replacement trees are also present between these productive tree layers, but obviously they do not have a definite place in the garden architecture. The different ensembles overlap, which induces a high degree of leaf cover (a cumulative canopy coverage of about $200 \%$ of the plot surface). When both nutmeg and cinnamon are present in the mixture, the lower ensemble becomes quite dense from the ground to $18 \mathrm{~m}$ high reducing the relative abundance of spontaneous components (which often occurs in nutmeg - or cinnamon - dominated gardens). Figure 4 shows the photograph of a garden with durian, Toona and nutmeg and Figure 5 is a photograph of a cinnamon-dominated garden.

3.2.2 Coffee and wood species established under trees. Most of the coffee gardens are newly established; they take the place of nutmeg gardens or are established in previously neglected gardens. The tree canopy in coffee gardens is not as dense as in other types and provides only $30-50 \%$ of relative cover. The coffee stand will occupy the space from the ground to $5 \mathrm{~m}$, with a stand density of 1500 bushes/ha. Various trees are introduced at the same 


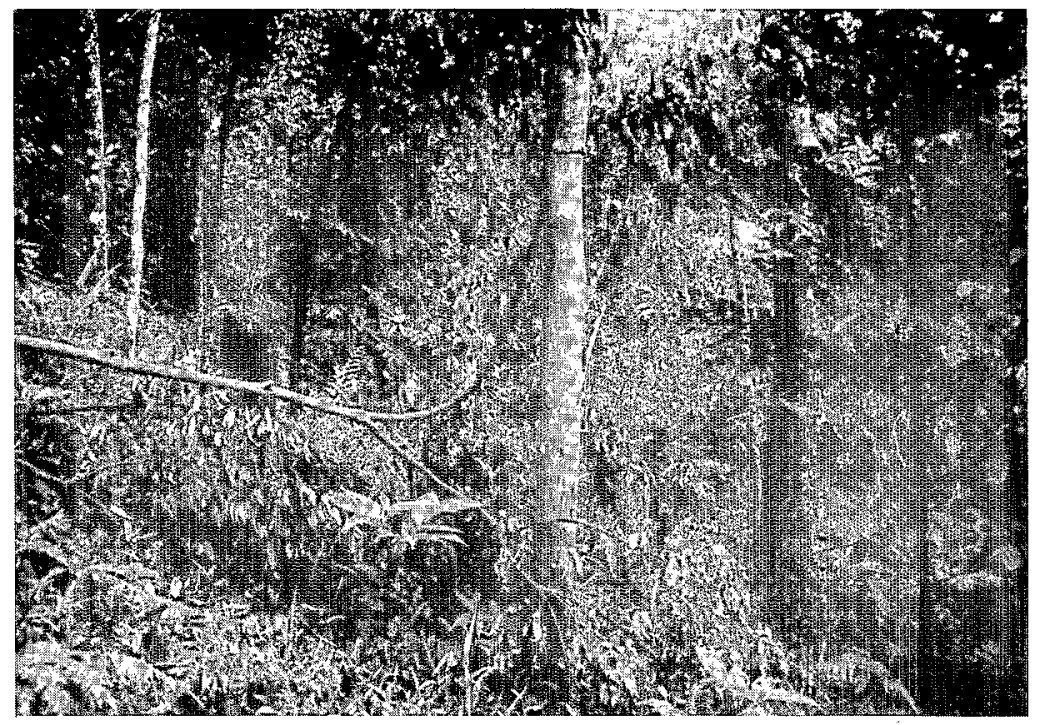

Figure 5. Bark of cinnamon being harvested in a cinnamon-dominated garden. (Photo: G. Michon)

time; they are mainly woody species which will form different layers when mature (i.e. within 20 to 30 years, when coffee declines). Pterospermum and Actinodaphne will reach the canopy ensemble whereas Toona and Alangium will constitute a lower ensemble ( 20 to $30 \mathrm{~m}$ ). During the establishment phase, bananas are also planted which form a productive lower ensemble from 0 to $2 \mathrm{~m}$. Coffee is often associated with cinnamon which will form another ensemble $(5-15 \mathrm{~m}$ ) with a low leaf-cover (density of the cinnamon stand being less than that in the first type).

The association and the interactions among the different types of gardens induce a complex mosaic on the slopes. Although the specific composition and configuration of individual gardens can change over time, the overall 'agroforest cover' remains stable in time and space. Changes from one type of garden to another, or from an abandoned garden to a renewed one often occur without any drastic change in the overall structure because clear-cutting and burning are avoided and replacement of crops and trees is progressively staggered so that the balance between the component canopies is usually maintained. Figures 6 and 7 show the schematic presentations of the structure of these two major types of agroforestry garden systems.

\subsection{Management}

In managing their gardens, the peasants adopt 'agricultural' practices (planting, clearing, manuring, cutting, etc.) and undertake integration of natural processes of organic matter and nutrient cycling and vegetation regeneration. 


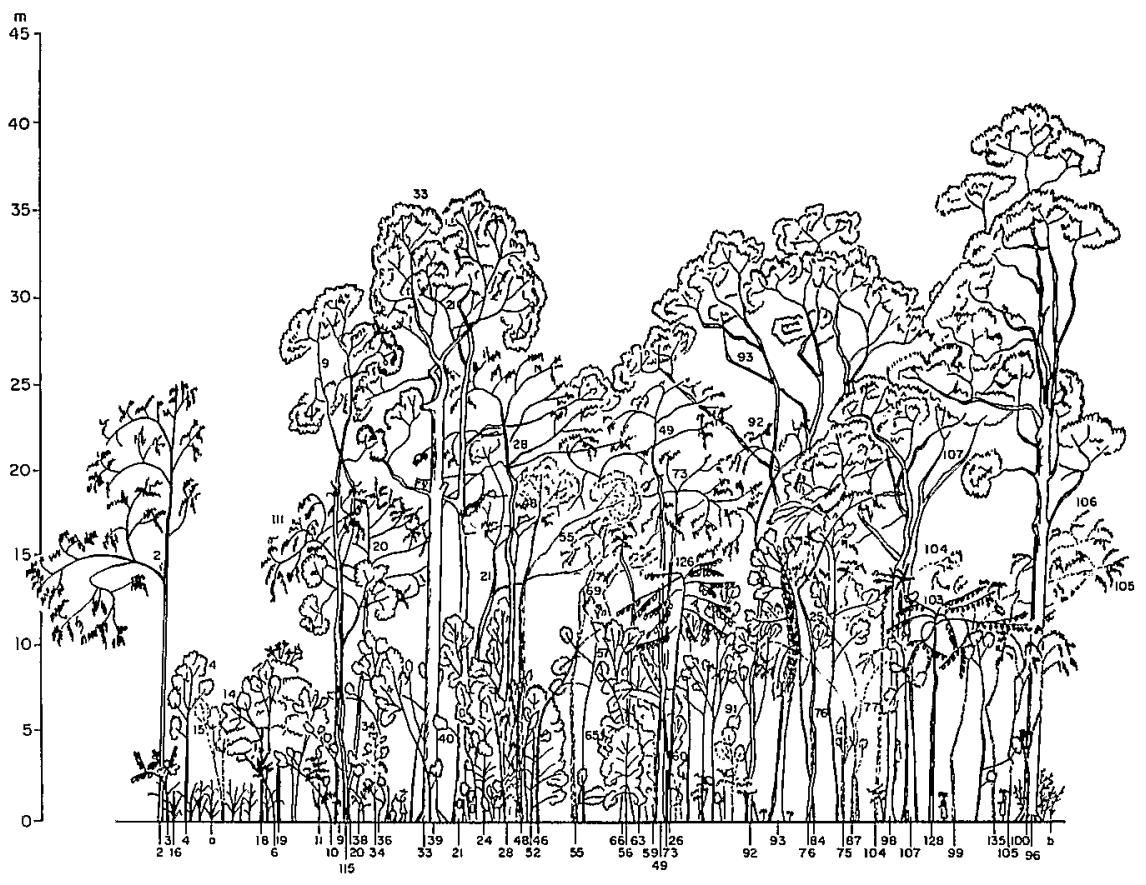

\begin{tabular}{|c|c|}
\hline terospermum javanicum. & $\begin{array}{r}2,28,46, \\
\text { nos. } 84,92,94,97,87,9\end{array}$ \\
\hline Durio zibethinus. & nos. $1,3,9,21,33,34,44,47,48,59,74,93,96,98,107$ \\
\hline Alangium kurzii & $\ldots \ldots \ldots \ldots$ nos. $45,103,106$ \\
\hline$\ldots \ldots$ & ${ }^{\prime} \ldots \ldots \ldots \ldots \ldots \ldots \ldots$ \\
\hline Bacco & $\ldots \ldots \ldots$ no. 18 \\
\hline Eugenio maloccensis & $\ldots$ no 19 \\
\hline ICo & $\ldots \ldots \ldots$ \\
\hline agrans & nos $22,24,52,56,67$ \\
\hline Coffed robusto & $\operatorname{nos} 6,10,11,36,38,80,82,127,128,144,152$ \\
\hline vor, somak & $\cdot \ldots \ldots$ \\
\hline hycladum & $\ldots \ldots \ldots \ldots \ldots, \ldots(b)$ \\
\hline num burmoni & os. \\
\hline
\end{tabular}

Figure 6. Schematic presentation of the structure of a 'Durian + wood species + cinnamon/nutmeg' combination.

The major determining factor in the maintenance of gardens is the functional interactions among plants - or between plants and soil - and among biological cycles of each individual plant.

Peasants have an intimate knowledge of the ecological requirements of agroforestry species. For example, cinnamon, a medium altitude species, when grown under $800 \mathrm{~m}$ a.s.1. is never put under direct light exposure, but is planted under a dense canopy which will maintain the optimum temperature and humidity. Toona, which is a 'gap' species in natural forests, cannot germinate under the shade of gardens. In order to get seedlings, peasants manage opened places near Toona trees by thinning the canopy and clearing 


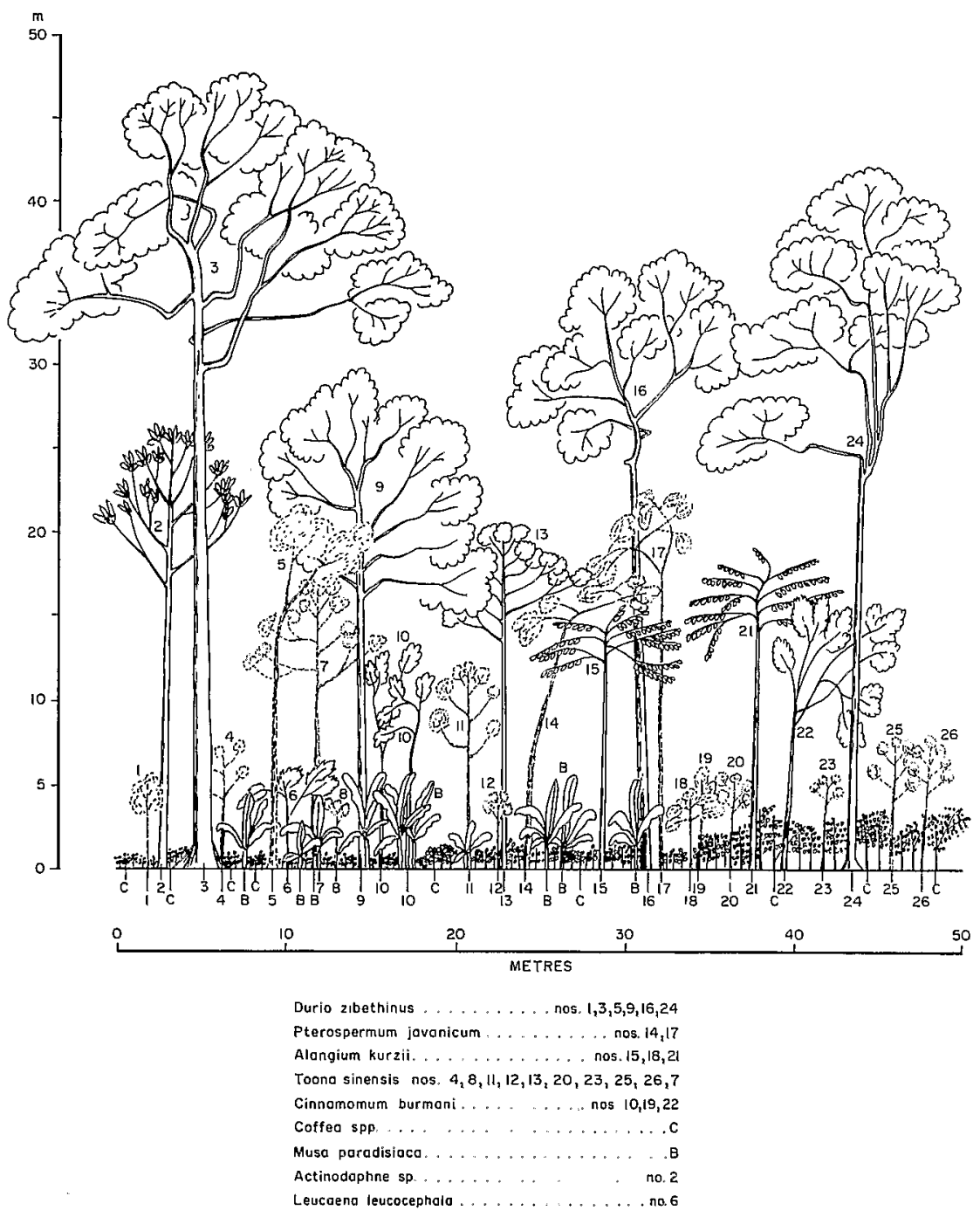

Figure 7. Schematic presentation of the structure of a 'coffee + timber species under traditional trees' combination.

the undergrowth, so that seeds produced by mature trees germinate and seedlings are transplanted after one or two years in chosen places when they can withstand shade.

Regular planting of seedlings is done for a few species only; even for the 'planted' species, it is not the exclusive way of reproduction. Planting is always complemented by natural regeneration. The main effect of planting is that the peasant can choose the place of the future tree, and promote a 
better growth by associating the seedling to decaying or decomposing trees which will ensure a better fertilization. Planting is also the only way when changing the composition of a garden, or renewing a dominant stand (cinnamon or coffee).

Except for coffee, cinnamon and wood species, trees are not eliminated before they die or fall down naturally. This natural elimination induces a free place in lower layers or a gap in the canopy, as chablis do in natural forests. Wood, if valuable, is collected, or left to decompose on the ground. The evolution of gaps can be summarized as follows:

- if the size of the gap is reduced, the increase in light at the ground level and the availability of space, stimulate the growth of replacement trees waiting in the undergrowth that soon close-up the opening;

- if no replacement trees are present, or if change is needed, the opened place is used for the introduction of new trees; seedlings are planted near the fallen wood, which will ensure a good fertilization;

- if the opening is wide (mainly in renewed gardens where trees are eliminated by the peasant, or after big storms), young seedlings will always be associated with short-cycle, light-demanding crops (bananas for example), which constitute a 'pioneer equivalent' phase and contain the development of natural pioneers; this practice, besides reducing the occurrence of natural seedlings and succession species, provides a good environment for the first stages of growth of the seedlings, which benefit from light shade, humidity, and care given to the banana crop.

In the case of wood species, harvest acts as a natural chablis and the evolution of the induced gap is the same as that described for natural chablis. But, for cinnamon, especially when the stand is harvested at one go, harvest induces an abrupt disruption of the garden structure. In order to avoid invasion by undesirable species and to promote a good regeneration of the cinnamon stand, clearings have to be repeated during the first three years, and thinning of the coppiced shoots is necessary.

The colonization of the ground layer of the agroforest by aggressive species (Eupatorium odoratum, Lantana camara, or Urticaceae species) can be an important factor and regular clearings are needed. Gardens are usually cleared before the durian season, but this clearing remains selective: ferns are encouraged (as valuable vegetables), and natural seedlings and saplings of interesting species are retained and looked-after.

Retaining natural seedlings concerns fruit species, and above all, wood species. These young trees can grow under conditions of important shade and produce straight poles. Trees with poor form (as Pterospermum, which branches soon) are pruned in order to promote a better shape and better yields.

Intimate association between crops consequently reduces the occurrence and the consequences of pest attacks. However, an important disease is reported for nutmeg in the southern part of the crater, which even threatens 
the cultivation of nutmeg. No treatment (chemical or biological) is available for the peasants. Some disease occurs for cinnamon also, but trees are attacked when they are 6 years old, and the bark can be collected when the trees begin to die. No problems are reported for wood species. For fruits, the main threat is the high degree of depredation by the wild fauna; in fruiting seasons, peasants try to scare away monkeys and squirrels by making loud noises in the gardens, but the effect of this method is only momentary.

\section{Systems functioning}

\subsection{Resource input and utilization}

4.1.1 Land: In each village, agroforest land is divided among clans, each clan owning a more or less large piece of land ranging from the village up to the forest. Within each clan's property, plots are allocated to individuals (the average size of the allocated area varies, according to the villages and families, from 0.01 to $3 \mathrm{ha}$, with a mean value of $0.63 \mathrm{ha}$ ). However, trees, except for cinnamon and sometimes coffee, are not allocated (see 2.4.1), and are harvested by the whole clan.

The land of ricefields is also allocated to individuals on the same basis. However, the topographic differences among the villages result in a great difference in ricefield area per family from village to village; means vary from 0.1 to 1.3 ha per family. Distribution patterns of garden land are more even among villages.

4.1.2 Labour: An average number of 5 persons per household is common with only a few young men of age between 18 and 35 years (because of outmigration: section 2.4.1). In the agroforest, only family labour is used. The peak season of farm operations is during the durian season, and at the time of cinnamon harvest. If needed, mutual help with other farmers is availed of for cinnamon harvest (men cutting the tree, women peeling the branches and carrying the bark to the village). Most tasks in the agroforest have no fixed period and can be staggered if needed. Firewood collection and clearing are usually done by women and planting by men; fruit collection is done by all the members of the family. Cutting and sawing up timber trees is done by specialized workers who are paid in kind (a part of the wood) or cash.

Garden works are delayed during the peak of labour in the ricefields such as land preparation or harvest. However, durian collection, which employs everyone in full time, is given the top priority; rice harvest can fail if it coincides with the durian season.

4.1.3 Capital and other inputs: There is no mechanization for the work in the gardens, and the use of animal power is minimal. However, some villages have a tractor for the land preparation in the ricefields, and buffaloes are also commonly used. The only tools used in the gardens are the machette, axes, sometimes chainsaws, and hoes. Seeds are collected from the agroforests. 
Table 3. Value of the agroforest product in two villages

\begin{tabular}{|c|c|c|c|c|}
\hline \multirow[t]{2}{*}{ Product } & \multirow{2}{*}{$\begin{array}{l}\text { Mean price } \\
\text { (Rp) }\end{array}$} & \multirow{2}{*}{$\begin{array}{l}\text { Home } \\
\text { consumption/ } \\
\text { sale }\end{array}$} & \multicolumn{2}{|c|}{ Total (million $\mathrm{Rp}$ ) } \\
\hline & & & Village 1 & Village 2 \\
\hline \multicolumn{5}{|l|}{ Cinnamon } \\
\hline $\begin{array}{l}\text { 1st quality } \\
\text { 2nd quality }\end{array}$ & $\begin{array}{l}680 / \mathrm{kg} \\
250 / \mathrm{kg}\end{array}$ & $0 / 100$ & 41.1 & 133.8 \\
\hline \multicolumn{5}{|l|}{ Nutmeg } \\
\hline $\begin{array}{l}\text { nuts } \\
\text { macis }\end{array}$ & $\begin{array}{l}1800 \text { to } 900 / \mathrm{kg} \\
1950 / \mathrm{kg}\end{array}$ & $\begin{array}{r}10 / 90 \\
0 / 10\end{array}$ & 3.6 & 15 \\
\hline Coffee & $1000 / \mathrm{kg}$ & $10 / 90$ & 16 & 30 \\
\hline Durian & 150 to $250 /$ fruit & $10 / 90$ & 17.5 & 165.5 \\
\hline Firewood & $300 /$ set & $70 / 30$ & 4 & 13.5 \\
\hline Timber & variable & $60 / 40$ & 20 & 25 \\
\hline Others & variable & $90 / 10$ & no data & no data \\
\hline $\begin{array}{l}\text { Rice } \\
192\end{array}$ & & $300 / \mathrm{kg}$ & variable & 285 \\
\hline \multicolumn{3}{|l|}{ Total value } & 387 & 514 \\
\hline \multicolumn{3}{|c|}{ Total value (agroforest only) } & 202 & 514 \\
\hline \multicolumn{3}{|c|}{ Total value/family } & $931000 \mathrm{Rp}$ & $1122000 \mathrm{Rp}$ \\
\hline \multicolumn{3}{|c|}{ Agroforest value/family } & $49000 \mathrm{Rp}$ & $93000 \mathrm{Rp}$ \\
\hline
\end{tabular}

1 US $\$=$ Rp. 1000 (approx; 1985)

Table 4. The role of agroforestry gardens (AFG) and rice field in satisfying the basic needs of the villagers

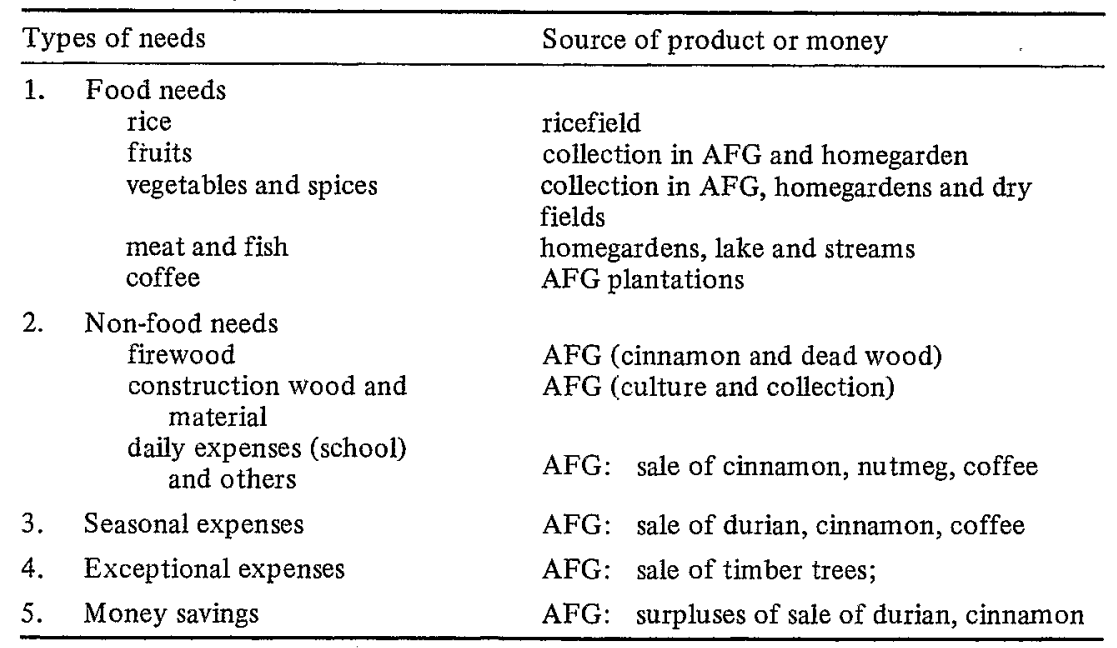

Pericarps and other wastes from durian or nutmeg and dried pericarp of coffee are used as manure, mainly for coffee; chemical fertilizers are not used.

\subsection{Production}

Production figures have been obtained for commercial products, but estimated for consumed products. Of the total income from agricultural produce 
(ricefields + gardens), the agroforest products account for 26 to $80 \%$. One hectare of garden produces 365000 to $5000000 \mathrm{Rp}$. (1000 Rp = 1 US Dollar in 1985); individual products of crops are given in Table 3. Total value of wood products is an under-estimate because only the commercialized part could be taken into account. The total value of products collected from wild plants is also unknown. The role of the agroforestry gardens in satisfying the basic needs of villages is given in Table 4 .

\section{System dynamics}

\subsection{Growth of the system}

Boundaries between ricefields and agroforests, or between agroforest and forest are well defined and already fixed. No expansion of agroforests has been reported in the recent times. However, some structural changes occur within the agroforestry $\mathrm{mix}$ itself. In some villages, the relatively large areas under rice provides surplus rice for cash sale; then agroforests are not well tended and they are used mainly for collection of products such as wood (fuel and construction), fruits, vegetables, etc. for domestic use.

Gardens located far away from villages ( $2 \mathrm{~h}$ up on the slopes), which were previously dominated by coffee, are also often abandoned. However, some of them are renewed by clearing and/or harvest of the coffee stand.

\subsection{Sustainability}

Though agroforests can yield a multiple of products for home consumption as well as for money, they are subject to changes consequent to the increase in population. The traditional out-migration (section 2.4.1) is a factor that can neutralize the effect of population growth, and maintain the system's continuity. Another determining factor in the agroforest's stability over time is the strict form of land tenure which conserves trees and land as an inalienable inheritance.

Failures have sometimes occurred for some of the commercial crops, e.g. coffee failure due to drastic drop in international prices (1940), and the present nutmeg failure due to severe pest problems. But they have not resulted in a general decrease in the area of the agroforest garden system. Because of the high diversity of species and their functions, and the lowinput nature, agroforests have a high degree of biological as well as economic stability and sustainability. They are also flexible systems: crops, or tree species, can be changed without affecting the overall structure and productivity. This induces an essential adaptability of gardens to changing economic conditions. The system's composition can be altered according to the economic situation: the subsistence and cash components can replace each other if needed. The main negative point is the low direct 'rentability' of the individual commercial crop, compared to the intensive monocrop plantations of the same species. But as export crops are high risk-enterprises, peasants in 
Maninjau prefer to stake on long term sustainability than on immediate rentability.

\section{Evaluation}

\subsection{Merits}

(1) The continuous ground cover on the slopes is a 'sine qua non' condition for the maintenance of the whole agricultural system. Agroforest cover, i.e. a close-cover, layered canopy, a diversified root system and a permanent soil cover by grasses and bushes, is essential to avoid disastrous landslides, and maintain soil fertility on slopes and stability of ricefields.

(2) Agroforests act as an efficient buffer zone between villages and the forest reserve. The ecological transition between forest and the opened agricultural lands is progressive; agroforests ensure a continuous extension of forest structures down to the villages and their simplified homegardens. Agroforests also represent a good forest substitute for peasant life: they produce wood, forest foods, material and money income, as natural forest traditionally do for forest people, and thus limit the intrusion of peasants into the forest reserve for gathering purposes. The protection of forest resources in the agroforest is increased since these resources are appropriated by families and managed in order to ensure their reproduction. Agroforests in Maninjau represent a good mode of efficient buffer system for natural forest protection.

(3) The great species diversity of agroforests represents a valuable gene bank for forest species as well as for domesticated species. Many species native to the original forest of the crater have been able to reproduce within the agroforest structure, which provides a humid and shady environment. The great Dipterocarp species have almost disappeared, but other valuable species of trees remain and reproduce in the agroforest. Various fruit and crop species represent years of selection (both natural and human). Durian, for example, has a great level of genetic diversity, and represents a valuable gene pool for breeding or improvement programmes.

(4) Export crops produced in Maninjau contribute to West Sumatra's exports, significantly cinnamon (50\% of the sub-province exports) and nutmeg (55), and to a lesser extent coffee (10\%). Wood for construction and fuel from agroforests supplies the surrounding, deforested areas while fully fulfilling the local needs.

(5) Income provided by agroforests is comparable to, or even greater than, that provided by ricefields (annual net income of 500000 to 80000 $\mathrm{Rp} /$ ha for ricefield, 365000 to $1210000 \mathrm{Rp} /$ ha for agroforest). Diversity of products, as well as production possibility allows a distribution of economic risks for the peasant. 


\subsection{Constraints and improvement needs}

(1) Technical support is not provided for agroforest as a system; extension workers deal with cinnamon, nutmeg, or coffee, as monocultural crops. Experiments for improvement or pest eradication are conducted in monocultural stands, and actual plant associations as practised by peasants are not taken into account. This is true also in the administrative aspects related to garden culture (which include mainly taxes on land and produce):- taxes are paid for wood and forest products to Forest Services, export crops are attached to Plantation Services and fruits to the Agricultural Services. This induces a complexity of management, and above all a complete misunderstanding of the agroforest system by administrative and technical services. This also is not to the benefit of peasants who have to pay different taxes to different services and sometimes to pay twice for the same product.

(2) Pest problems (see Section 3.3.3) have not been solved until now. In the southern part of the crater where nutmeg and durian are attacked heavily by insect pests, and disastrous landslides have also occurred, peasants believe in global 'illness' or 'exhaustion' of the land caused by 'spirits' and prefer to migrate outside the area.

(3) Production levels from the gardens are fairly low. Clonal variations and irregularities in fruiting seasons cause high variability in the production of coffee, nutmeg, and durian from year to year. This situation could be improved by using regular cultivars as well as improved management methods (pruning, cutting, etc.).

(4) Peasants have no possibility to exert any control over prices for export crops. Cooperatives for trade are limited to a few villages and should be promoted to ensure a better control with storage possibilities, credit opportunities, and power for negotiation with the wholesale dealers in Padang.

(5) Animal husbandry is not developed in Maninjau as in the surrounding areas. Agroforests could provide a good basis for commercial husbandry with cows or buffaloes, with regulated grazing or integrated use of ground cover as forage producer.

\subsection{Extrapolability}

Agroforests in Maninjau provide a good example that could serve as a basis in the following:

- Modelling efficient buffer zones around protected forests. Interesting practices and strategies of integration of forest resources into the agroforest structure through cultivation of forest species and protection of natural components can be learned from the agroforest in Maninjau.

- Promoting peasant integrated silvicultures for timber. The variety of wood species and silvicultural practices to each could serve as an example for the surrounding area. Forest Services undertake 'regreening' programmes near 
Bukkittinggi, but they often use exotic species, seedlings of which are expensive for the peasant (these are 'government species' for the peasant who is reluctant to plant, or protect them). Integrated wood production based on local species would have better chances to succeed, and the valuable species can be found in the Maninjau system.

- Growing cash crops under a canopy of useful trees. Peasants in Maninjau have developed successful methods to manage export crops within a complex tree structure. These methods though still need to be improved, can serve as a basis for the promotion of commercial agroforests in similar areas. However, the success of Maninjau agroforestry system is closely linked to a particular social system. Extrapolating this type of agroforest to other areas with different socio-economic backgrounds can be problematic. At least, the influence and the impact of land tenure system, and traditional laws and customs have to be thoroughly studied in each particular case.

\subsection{Research needs}

The present study did not get detailed information on:

- qualitative and quantitative interactions between plants and soil in the different types of associations;

- positive and negative effects between associated plants, as far as yields or pests are concerned; and

- precise production data for commercial and subsistence products in different villages, as well as the variability of production during the year and over the years.

In addition to the above, information on the following is also needed:

- improving the use of ground layer (by forage plants or valuable crops);

- better soil management techniques, especially for soil 'rehabilitation' after nutmeg cultivation;

- use of compost, green manure or nitrogen fixing plants in order to improve yields or export crops; and

- the integrated use of pioneer plants such as Eupatorium, Lantana, and trees such as Laportea, Pisonia, that are traditionally known as soil improvers.

\section{References}

1. Agam Dalam Angka (1981 and 1982) Departmental and district statistics

2. Bahri S (1984) Plantes utiles de sous-bois; une perspective en agroforesterie. Dea Univ Montpellier, France

3. Mary F (1986) Agroforêts et sociétés; étude comparée de trois systèmes agroforestiers indonesiens. Dr Thesis, Ensa Montpellier, France, 2 vol

4. Michon G, Bompard J, Ducatillion C and Hecketsweller P (1983) Tropical forest architectural analysis as applied to agroforests in the humid tropics: the example of traditional village agroforests in West Java. Agroforestry Systems 1(2): 118-129

5. Michon G (1985 De l'homme de la foret au paysan de l'arbre: agroforesteries indonesiennes. $\mathrm{PhD}$ Thesis, Univ Montpellier, France 
6. Naim M (1973) Merantau: Minangkabau voluntary migration in West Sumatra. Dissert Fac of Arts \& Sc, Univ of Singapore

7. Ogino K, Hotta M, Tamin R and Yoneda T (1984) Forest ecology and flora of Gunung Gadut, West Sumatra. Sumatra Nature Study (Botany), Kyoto, Japan

8. OK Kung Pak (1982) Ideology and practice of the matrilineal land tenure system in West Sumatra. Inst of South East Asia Studies, Singapore

9. Schrieke B (1955) The causes and effect of communism on the west coast of Sumatra. Indon Sociol Studies, The Hague Bandung van Hoeve

10. Scholz U (1983) The natural regions of Sumatra and their agricultural production patterns. Crifc Bogor Indonesia 2 vol 